\title{
Marketing foods to children: a comparison of nutrient content between children's and non-children's products
}

\author{
Amelia Lythgoe ${ }^{1}$, Caireen Roberts ${ }^{2, *}$, Angela M Madden ${ }^{1}$ and Kirsten L Rennie ${ }^{1}$ \\ ${ }^{1}$ School of Life and Medical Sciences, University of Hertfordshire, Hatfield, UK: ${ }^{2}$ NatCan Social Research, \\ 35 Northampton Square, London ECIV OAX, UK
}

Submitted 15 May 2012: Final revision received 20 February 2013: Accepted 26 February 2013: First published online 2 May 2013

\begin{abstract}
Objective: The predominance of marketing of products high in fat, sugar and/or salt to children has been well documented and implicated in the incidence of obesity. The present study aimed to determine whether foods marketed to children in UK supermarkets are nutritionally similar to the non-children's equivalent, focusing on food categories that may be viewed as healthier options. Design: Nutritional data were collected on yoghurts ( $n$ 147), cereal bars ( $n$ 145) and ready meals ( $n$ 144) from seven major UK supermarkets and categorised as children's or non-children's products based on the characteristics, promotional nature or information on the product packaging. Fat, sugar and salt content was compared per $100 \mathrm{~g}$ and per recommended portion size.

Setting: UK.

Results: Per $100 \mathrm{~g}$, children's yoghurts and cereal bars were higher in total sugars, fat and saturated fat than the non-children's; this was significant for all except sugar and total fat in cereal bars. Per portion these differences remained, except for sugars in yoghurts. Conversely children's ready meals were significantly lower in these nutrients per portion than non-children's, but not when expressed per $100 \mathrm{~g}$. Children's yoghurts and ready meals had significantly lower sodium content than non-children's both per portion and per $100 \mathrm{~g}$.

Conclusions: Significant differences between the nutritional composition of children's and non-children's products were observed but varied depending on the unit reference. A significant number of products marketed towards children were higher in fat, sugar and salt than those marketed to the general population.
\end{abstract}

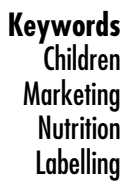

It is estimated $38 \%$ of all European children are overweight or obese ${ }^{(1-3)}$. Childhood obesity and poor nutrition are linked to health complications such as type 2 diabetes, dental caries and increased risk of obesity and chronic diseases later in life ${ }^{(4-6)}$.

In the UK, the National Diet and Nutrition Survey 2008-09 found the intake of non-milk extrinsic sugars in 4-18-year-olds to be $15 \%$ of total energy intake, above the dietary reference value of no more than $10 \%$; saturated fat intake also exceeded the dietary reference value of $10 \%(7,8)$. These factors may contribute to rising obesity levels ${ }^{(1)}$. This pattern is reflected in other countries in Europe, with the intake of total fat being above the WHO-recommended $30 \%$ of energy intake and saturated fat intake generally being greater than $10 \%{ }^{(9,10)}$. The marketing of energy-dense foods of poor nutritional quality to children may contribute to the rise in childhood obesity and has been highlighted as a cause for concern ${ }^{(10,11)}$. WHO recommends governments as key stakeholders in specifying policies and mechanisms which will reduce the exposure and impact of marketing of foods high in fat, sugars or salt to children ${ }^{(12)}$.
Marketing is described broadly as 'a mechanism for influencing behaviour' ${ }^{(13)}$. Marketing to children focuses on food; in particular high fat, sugar and/or salt (HFSS) products $^{(14,15)}$. There is evidence verifying that food promotion influences children's consumption, purchasing behaviour and requests, known as 'pester power'(4,13,16,17). Children are targeted due to their ability to influence household purchases, their own increasing purchasing power and their potential as lifetime consumers ${ }^{(13,18)}$. Food promotion to children influences both brand and type of food purchased ${ }^{(13)}$. Use of characters, particularly familiar, age-appropriate cartoons, promotes fun and encourages children to form attachments ${ }^{(16,18,19)}$.

Links have been established between extensive television advertising of HFSS foods and obesity in children ${ }^{(13)}$. Television advertising is subject to statutory legislation; the UK ban on advertising unhealthy foods around children's programmes is recognised as one of the most comprehensive schemes to be implemented ${ }^{(11,20-23)}$.

Most research into the effects of television advertising focuses on the promotion of HFSS products, i.e. confectionery 
and soft drinks ${ }^{(4,13,14,23)}$. There has also been extensive work demonstrating that breakfast cereals marketed to children are more likely to be $\operatorname{HFSS}^{(21,24)}$. Assessment of other children's products has been performed in countries such as the USA, Canada and Australia, but little research has been undertaken in Europe ${ }^{(14,18,23,25,26)}$. Existing studies evaluating the differences between children's products and non-children's products have either included baby and toddler foods only or have been limited to small sample sizes ${ }^{(13,27)}$.

The present study aimed to determine whether foods marketed to children in UK supermarkets are less healthy than those not marketed to children. Yoghurts (including fromage frais), cereal bars and ready meals were selected for comparison as these may be viewed as healthier options. Yoghurts represent the greatest proportion of milk and milk products consumed by children under the age of 10 years excluding milk ${ }^{(28)}$. Cereal bars are often selected as a 'healthier' option to traditional chocolate bars $^{(29)}$. 'Ready meal' is a recognised food category within the European Commission; the category can be further divided into chilled, frozen, canned and ambient types ${ }^{(30,31)}$ and the current research focused on chilled and frozen sectors. Infant ready meals are a rapidly expanding market segment that has recently increased its presence in chilled food aisles of supermarkets ${ }^{(32)}$. There is also a predominance of child-oriented packaging for these items which allowed comparison against an equivalent. Confectionery, fast food and soft drinks were not included as these are already known to be $\operatorname{HFSS}^{(4,18)}$ and research has already been undertaken worldwide for breakfast cereals ${ }^{(21,24)}$.

\section{Materials and methods}

Nutritional data were collected between November 2010 and March 2011 from online and in-store packaging information from UK supermarkets, as described in similar studies $^{(17,24,33)}$. Seven major UK supermarkets were used to cover different socio-economic categories. The supermarkets chosen represent over $85 \%$ of the market share in the $\mathrm{UK}^{(34)}$. Nutrients included energy (kilojoules), protein, carbohydrate, sugars, fat, saturated fat, fibre and sodium (all in grams). Calcium was included for yoghurts. Data were collected per $100 \mathrm{~g}$ as required by UK Food Labelling Regulations ${ }^{(35,36)}$. Data per portion size were obtained from packaging information or calculated based on recommended serving size and information per $100 \mathrm{~g}^{(37)}$.

Children's food items were identified by statements such as 'little'/'kids'; specified age range; use of characters or celebrities for marketing; links with children's media; fun or fantasy themes; and/or promoted for lunchboxes $^{(18,23,24,38)}$. Non-children's food products were selected from the same food categories but without the qualifying features above.
Certain products were excluded such as those deemed as specialised or novel foods. Yoghurt exclusions were those with stanols and sterols as these are directed at adults; pre/probiotic yoghurts as there were insufficient children's products to enable fair comparisons; non-cow's milk yoghurts; and products where yoghurt content was below 90\%. All other yoghurt types and brands were included. Cereal bars exclusions were specialised free from' ranges and those with less than 50\% cereal grains. All other cereal types and brands were included.

For ready meals, products were categorised into meal type depending on protein and carbohydrate source. These were beef \& pasta, beef \& potato, chicken \& pasta, chicken \& potato, chicken \& rice, fish \& pasta, fish \& potato, pork \& pasta, pork \& potato, and vegetable \& pasta dishes. This categorisation is used in the current National Diet and Nutrition Survey in the $\mathrm{UK}^{(7)}$. A range of children's products was selected within each type and non-children's equivalents included to the equivalent number per category.

A small number of nutrients were labelled as 'trace'; these were designated $0 \cdot 05 \mathrm{~g} / 100 \mathrm{~g}$ to enable analysis. This is in accordance with the Food Standards Agency's Food Labelling Regulations, which state that 'trace' can be used for values below $0 \cdot 1 \mathrm{~g} / 100 \mathrm{~g}$ and values between $0 \cdot 05$ and $0 \cdot 15 \mathrm{~g} / 100 \mathrm{~g}$ may be rounded to this ${ }^{(35)}$. It was considered that $0.05 \mathrm{~g} / 100 \mathrm{~g}$ would be more suitable than using $0 \mathrm{~g} / 100 \mathrm{~g}$ as nil is a permissible value and could be used if manufacturers deemed appropriate ${ }^{(35)}$.

\section{Statistical analysis}

Comparisons were made between children's and nonchildren's products for nutrients (per $100 \mathrm{~g}$ and per recommended portion). A Kolmogrov-Smirnov analysis was used to test the normality of the distribution; the Mann-Whitney $U$ test or independent-samples $t$ test was then used, depending on the findings of normality, to compare the nutrient content of children's $v$. non-children's products in the three different product categories. The significance of these tests was based on a 95\% confidence interval. Energy contribution from fat and sugars was calculated using Atwater conversion figures ${ }^{(39)}$. Percentage of fat as saturated was also calculated and compared using an independent $t$ test. Statistical analyses were performed using the statistical software package PASW Statistics 18 at a $95 \%$ confidence interval.

\section{Results}

A total of 436 products were analysed: 147 yoghurts of which sixty were categorised as children's and eightyseven non-children's; 145 cereal bars of which forty-three were children's and 102 non-children's; and 144 ready meals of which seventy-one were children's and seventythree non-children's. 


\section{Nutritional composition}

Children's yoghurts contained significantly higher levels of energy $(P<0 \cdot 001)$, carbohydrate $(P=0 \cdot 045)$, sugars $(P=0 \cdot 014)$, fat and saturated fat (both $P<0 \cdot 001$ ) per $100 \mathrm{~g}$ than non-children's products (Table 1). Conversely, there was a significantly lower level of sodium in children's products compared with non-children's $(P<0 \cdot 001)$. There was no significant difference in the amount of calcium in children's $v$. non-children's yoghurts. For cereal bars, there were no significant differences between children's and non-children's per $100 \mathrm{~g}$, except for saturated fat which was significantly higher in children's cereal bars $(P=0 \cdot 002)$. For ready meals children's products had significantly lower values for energy $(P<0 \cdot 001)$, protein $(P=0 \cdot 030)$, carbohydrate and sodium (both $P<0 \cdot 001)$ per $100 \mathrm{~g}$, yet sugar and fat contents were not significantly different.

Figures 1-3 show the nutrient distribution per $100 \mathrm{~g}$ along with the UK Food Standards Agency boundaries for high, medium and low amounts of sugars, fats and salt presented for reference ${ }^{(40,41)}$. These plots show the range of nutrient distribution in the products sampled, including the extreme values. For yoghurts, the greatest range was in non-children's products; cereal bars had a consistent distribution, except for saturated fat. Most children's yoghurts were above the medium boundary for fats and a higher proportion of children's cereal bars fell in the high category for saturated fat. For ready meals the difference in sodium between categories is clearly demonstrated, with meal types with highest/lowest values (i.e. outliers) indicated.

When expressed as nutritional values per portion, differences were observed in the results compared with per $100 \mathrm{~g}$ (Table 2). On average, children's products were significantly smaller than non-children's. However, fat $(P=0 \cdot 001)$ and saturated fat $(P<0 \cdot 001)$ were higher in children's yoghurts than non-children's. For cereal bars, children's products were significantly higher than nonchildren's in saturated fat and sodium (both $P<0 \cdot 001$ ). In ready meals, all nutrients were higher in non-children's meals, significant $(P<0 \cdot 001)$ for all but saturated fat. Further analysis within meal type showed no significant differences between children and non-children's products, except for pork \& potato meals which contained significantly more sodium in non-children's $(P<0 \cdot 001)$, likely to be due to those containing sausages.

\section{Energy proportions from fat and sugars}

Expressed as a percentage of the energy per $100 \mathrm{~g}$, children's yoghurts had a significantly higher level of energy from fat compared with non-children's yoghurts $(P<0 \cdot 001$; Table 3). Conversely, for non-children's yoghurts there were higher levels of energy from sugars $(P<0 \cdot 001)$. For cereal bars, children's products had a higher percentage of energy from sugars $(P=0 \cdot 047)$. Similarly, children's ready meals had significantly more energy from sugars than the

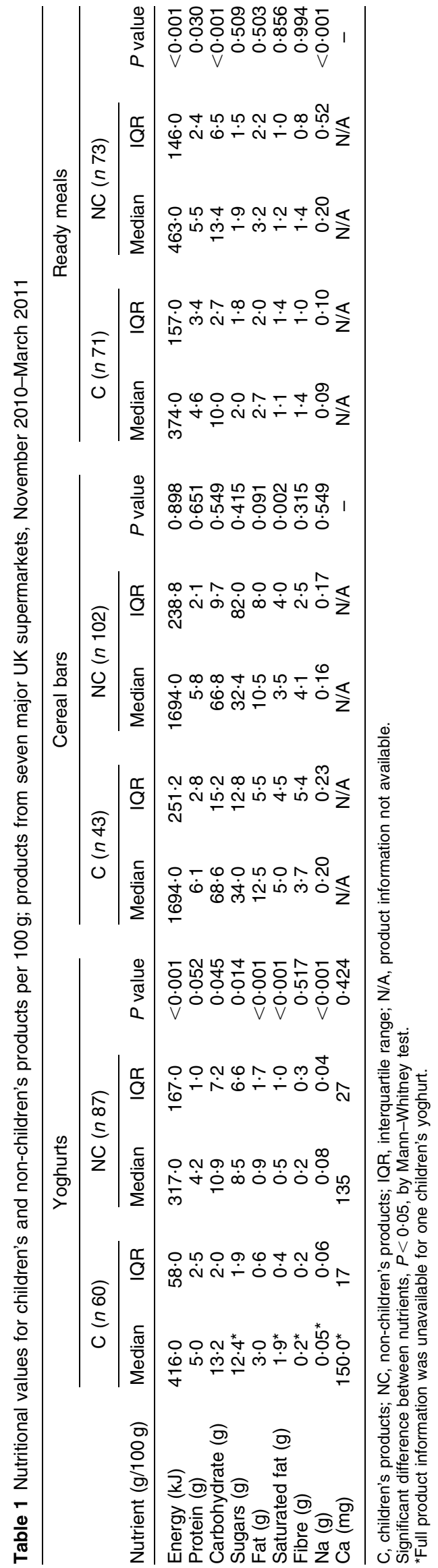



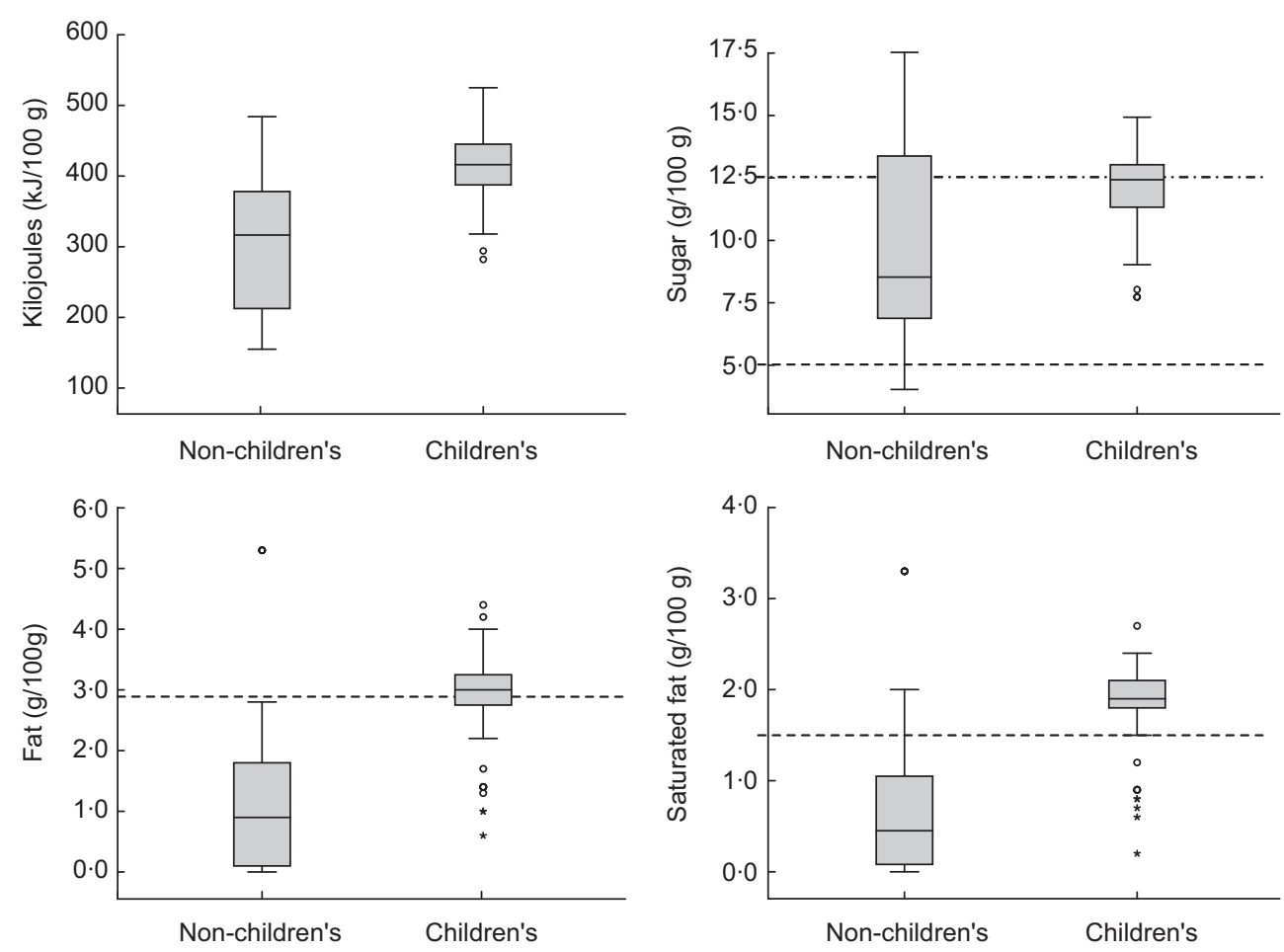

\begin{tabular}{llll}
\hline & \multicolumn{2}{c}{ FSA boundaries: criteria for traffic light labelling for food per $100 \mathrm{~g}$} \\
\cline { 2 - 4 } Ingredient & Green (low content) & Amber (medium content) & Red (high content) \\
\hline Fat & Less than $3 \mathrm{~g}$ & Between $3 \mathrm{~g}$ and $20 \mathrm{~g}$ & More than $20 \mathrm{~g}$ \\
Saturated fats & Less than $1.5 \mathrm{~g}$ & Between $1.5 \mathrm{~g}$ and $5 \mathrm{~g}$ & More than $5 \mathrm{~g}$ \\
Sugar & Less than $5 \mathrm{~g}$ & Between $5 \mathrm{~g}$ and $12.5 \mathrm{~g}$ & More than $12.5 \mathrm{~g}$ \\
Salt & Less than $0.3 \mathrm{~g}$ & Between $0.3 \mathrm{~g}$ and $1.5 \mathrm{~g}$ & More than $1.5 \mathrm{~g}$ \\
\hline
\end{tabular}

Fig. 1 The distribution of nutrients per $100 \mathrm{~g}$ in yoghurts $(n 147)$ marketed to children in seven major UK supermarkets, November 2010-March 2011. Data are presented as box-and-whisker plots in which $\square$ represents the interquartile range; the bottom and top of the whisker represent the minimum and maximum value, respectively; — represents the median; $O$ represent outliers; * represent extreme values. - - - UK Food Standards Agency (FSA) boundary for a high amount of sugars, fats or salt ${ }^{(40,41)}$; ,-- FSA boundary for a medium amount of sugars, fats or salt ${ }^{(40,41)}$

non-children's products $(P=0 \cdot 004)$. Children's cereal bars had a significantly higher percentage of total fat as saturated fat than non-children's equivalents $(P<0 \cdot 001)$.

\section{Discussion}

The present study compared nutritional information for products marketed towards children with their nonchildren's equivalents. Yoghurts, cereal bars and ready meals marketed towards children had significantly different nutritional profiles from those aimed at the general population. In most cases products marketed to children were higher in sugars, fat, saturated fat and/or sodium, with the exception of children's ready meals, which had lower sodium content than non-children's. It is important to note the different results depending on whether nutrients were assessed per $100 \mathrm{~g}$ or per portion. Comparisons by portion may be more meaningful given that these products will mostly be eaten per portion and, for young children, perhaps in even smaller amounts. However, the results per $100 \mathrm{~g}$ illustrate the difference in nutrient density between categories.

For all categories, non-children's versions that were noted as 'diet' or manufactured by weight-loss promotion companies were not included in the analysis as children's versions are not available to enable fair comparisons. However, for yoghurts where low-fat versions are part of the normal category range, these were included. The results highlight that for non-children's yoghurts fat reduction may be counteracted with sugar addition, emphasising the need for consumers to read labels.

Findings from the present investigation for yoghurts and cereal bars agree with those from other studies, namely that children's products are often $\operatorname{HFSS}^{(14,24,27)}$. In Canada, sodium in children's ready meals was found to be markedly higher than in the non-children's product equivalent ${ }^{(33)}$. Our study of UK products did not find this. There has been a UK government campaign for food manufacturers to lower salt in products, which may have 

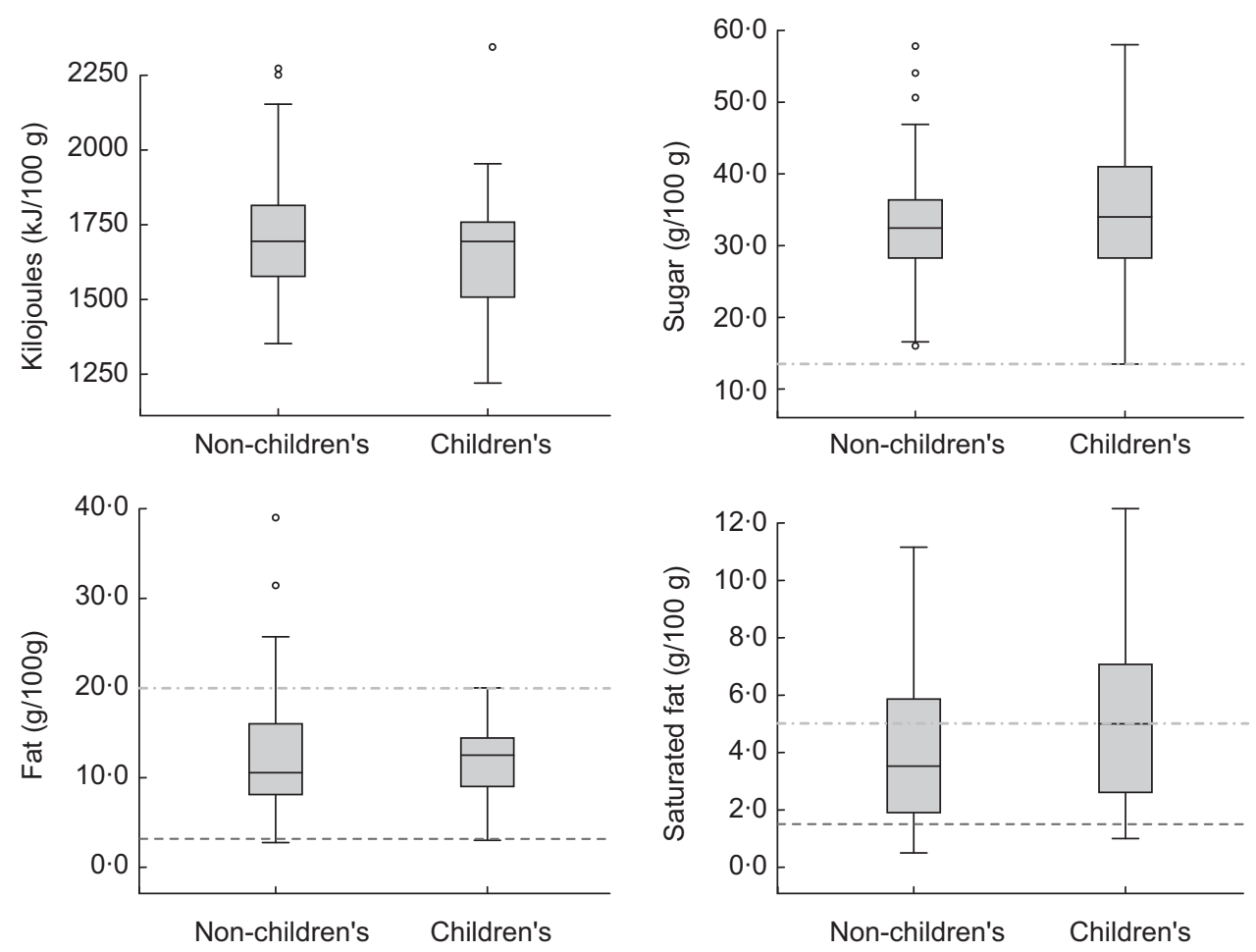

\begin{tabular}{lccl}
\hline & \multicolumn{3}{c}{ FSA boundaries: criteria for traffic light labelling for food per $100 \mathrm{~g}$} \\
\cline { 2 - 4 } Ingredient & Green (low content) & Amber (medium content) & Red (high content) \\
\hline Fat & Less than $3 \mathrm{~g}$ & Between $3 \mathrm{~g}$ and $20 \mathrm{~g}$ & More than $20 \mathrm{~g}$ \\
Saturated fats & Less than $1.5 \mathrm{~g}$ & Between $1.5 \mathrm{~g}$ and $5 \mathrm{~g}$ & More than $5 \mathrm{~g}$ \\
Sugar & Less than $5 \mathrm{~g}$ & Between $5 \mathrm{~g}$ and $12.5 \mathrm{~g}$ & More than $12.5 \mathrm{~g}$ \\
Salt & Less than $0.3 \mathrm{~g}$ & Between $0.3 \mathrm{~g}$ and $1.5 \mathrm{~g}$ & More than $1.5 \mathrm{~g}$ \\
\hline
\end{tabular}

Fig. 2 The distribution of nutrients per $100 \mathrm{~g}$ in cereal bars ( $n$ 145) marketed to children in seven major UK supermarkets, November 2010-March 2011. Data are presented as box-and-whisker plots in which $\square$ represents the interquartile range; the bottom and top of the whisker represent the minimum and maximum value, respectively; — represents the median; $\bigcirc$ represent outliers; represent extreme values. - - - UK Food Standards Agency (FSA) boundary for a high amount of sugars, fats or salt $^{(40,41)} ;---$, FSA boundary for a medium amount of sugars, fats or salt ${ }^{(40,41)}$

contributed to the lower salt in children's products, particularly yoghurts and ready meals ${ }^{(42)}$. Low salt in products is not only important for long-term health, but also in developing children's taste preferences ${ }^{(33,43)}$.

The strengths of the present study are its large sample sizes, the objective approach in identifying products and the comparison of nutrient content per $100 \mathrm{~g}$ and per portion, which provided more detailed findings. All major supermarket chains in the UK were chosen to ensure diversity and to include a range of socio-economic target populations. This avoided discrepancy due to the reported association of advertising HFSS food to people with financial restrictions ${ }^{(44)}$. Most product information was collected online from supermarket or company websites and included a variety of branded and own-label products to ensure that product availability due to location or socio-economic status of an area did not lead to impartiality ${ }^{(44-46)}$.

Limitations of the present study are that portion size was based on the manufacturer's recommended amount and may not be representative of what is actually eaten by different consumer populations ${ }^{(47,48)}$. The study does not cover all foods aimed at children, but concentrated on a systematic assessment of three food types - yoghurts, cereal bars and ready meals. The design of the study could be improved by laboratory analysis of a sample to validate nutrition labelling. Discrepancies were noted in energy content of products where kcal and $\mathrm{kJ}$ did not correspond. To thoroughly determine nutritional values and ingredients, individual companies could be contacted, in particular for added sugars.

Differences in nutrient requirements between children and adults and target age range for products also influence interpretation of results. For example, children under 12 years of age generally have lower energy needs compared with adults, and therefore lower fat, carbohydrate and protein requirements ${ }^{(8)}$. It follows that saturated fat and sugars should be less ${ }^{(8)}$ and this has been achieved for ready meals, and partially for yoghurts, by making, on average, children's products smaller. Only children's ready meals specified an age range, generally 

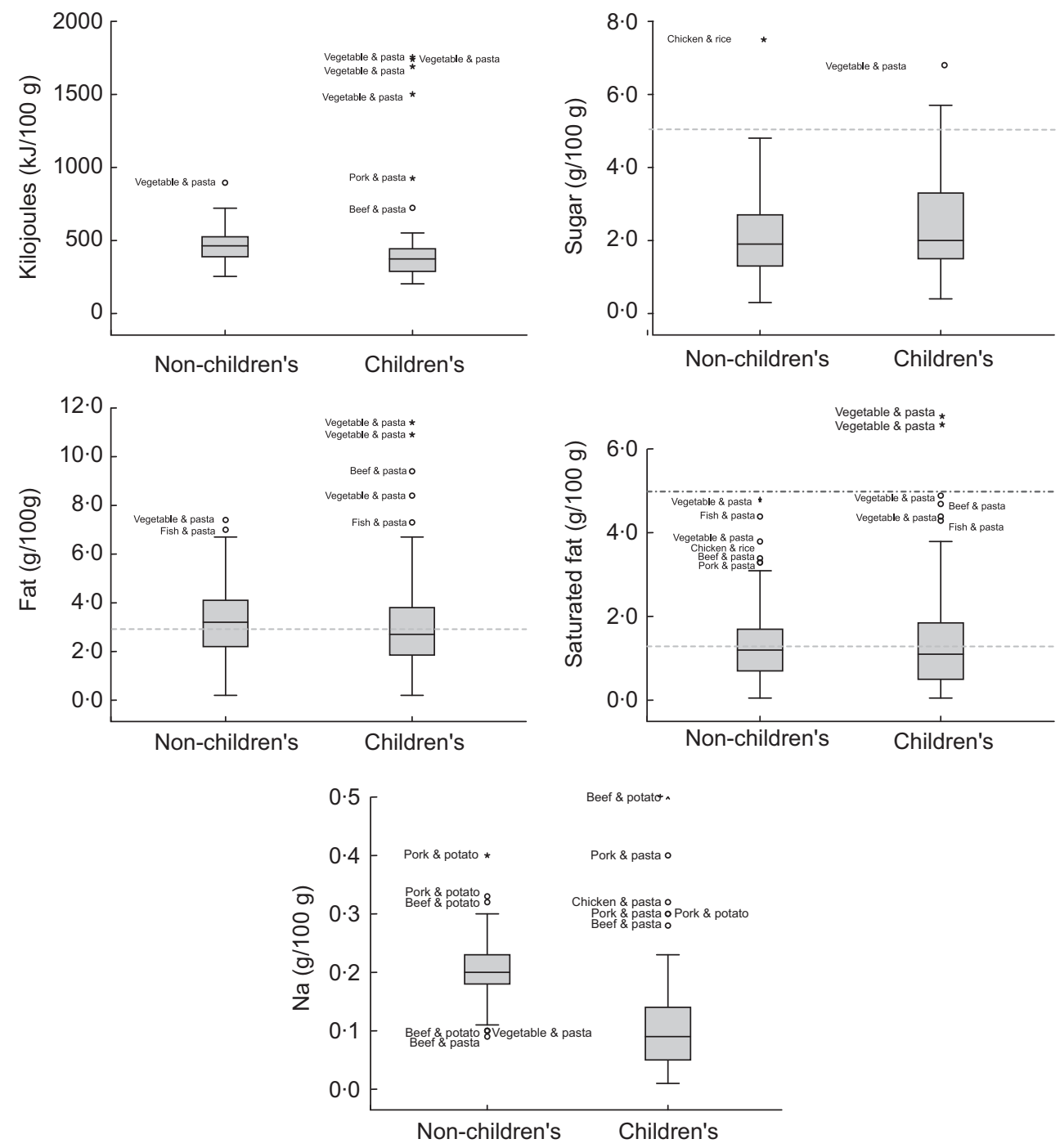

\begin{tabular}{lccc}
\hline & \multicolumn{2}{c}{ FSA boundaries: criteria for traffic light labelling for food per $100 \mathrm{~g}$} \\
\cline { 2 - 4 } Ingredient & Green (low content) & Amber (medium content) & Red (high content) \\
\hline Fat & Less than $3 \mathrm{~g}$ & Between $3 \mathrm{~g}$ and $20 \mathrm{~g}$ & More than $20 \mathrm{~g}$ \\
Saturated fats & Less than $1.5 \mathrm{~g}$ & Between $1.5 \mathrm{~g}$ and $5 \mathrm{~g}$ & More than $5 \mathrm{~g}$ \\
Sugar & Less than $5 \mathrm{~g}$ & Between $5 \mathrm{~g}$ and $12.5 \mathrm{~g}$ & More than $12.5 \mathrm{~g}$ \\
Salt & Less than $0.3 \mathrm{~g}$ & Between $0.3 \mathrm{~g}$ and $1.5 \mathrm{~g}$ & More than $1.5 \mathrm{~g}$ \\
\hline
\end{tabular}

Fig. 3 The distribution of nutrients per $100 \mathrm{~g}$ in ready meals ( $n$ 144) marketed to children in seven major UK supermarkets, November 2010-March 2011. Data are presented as box-and-whisker plots in which $\square$ represents the interquartile range; the bottom and top of the whisker represent the minimum and maximum value, respectively; —— represents the median; $\bigcirc$ represent outliers; represent extreme values. - - - UK Food Standards Agency (FSA) boundary for a high amount of sugars, fats or salt $^{(40,41)} ;---$, FSA boundary for a medium amount of sugars, fats or salt ${ }^{(40,41)}$

1-3 years. Energy and protein could be analysed further to look at percentage contribution to dietary reference values, assuming a meal provides a third of daily intake. Children's ready meals are within this range; however, it is beyond the scope of the present study to fully evaluate this here and there are obvious limitations as these requirements are based on a 'reference child' ${ }^{\text {(8) }}$. As the other products do not specify a target age range this analysis could not be extended further. Quantity of consumption also needs consideration; yoghurts and cereal bars are normally viewed as snacks and would be taken in smaller amounts than ready meals, but these could be consumed more frequently than ready meals.

Nutritional labelling has been well debated elsewhere, particularly the contribution of added sugars to energy intake ${ }^{(21,23,49)}$. Although children may not regularly use 
Table 2 Nutritional values for children's and non-children's products per portion; products from seven major UK supermarkets, November 2010-March 2011

\begin{tabular}{|c|c|c|c|c|c|c|c|c|c|c|c|c|c|c|c|}
\hline \multirow[b]{3}{*}{ Nutrient (g/portion) } & \multicolumn{5}{|c|}{ Yoghurts } & \multicolumn{5}{|c|}{ Cereal bars } & \multicolumn{5}{|c|}{ Ready meals } \\
\hline & \multicolumn{2}{|c|}{$C(n 60)$} & \multicolumn{2}{|c|}{$\mathrm{NC}(n 87)$} & \multirow[b]{2}{*}{$P$ value } & \multicolumn{2}{|c|}{$C(n 43)$} & \multicolumn{2}{|c|}{ NC $(n$ 102) } & \multirow[b]{2}{*}{$P$ value } & \multicolumn{2}{|c|}{$\mathrm{C}(n 71)$} & \multicolumn{2}{|c|}{$\mathrm{NC}(n 73)$} & \multirow[b]{2}{*}{$P$ value } \\
\hline & Median & IQR & Median & IQR & & Median & IQR & Median & IQR & & Median & IQR & Median & IQR & \\
\hline Portion size (g) & $82 \cdot 5$ & $50 \cdot 0$ & $125 \cdot 0$ & $5 \cdot 0$ & $<0.001$ & $28 \cdot 0$ & $10 \cdot 0$ & $30 \cdot 0$ & $12 \cdot 0$ & 0.001 & $230 \cdot 0$ & $60 \cdot 0$ & $395 \cdot 0$ & $50 \cdot 0$ & $<0.001$ \\
\hline Energy (kJ) & $326 \cdot 0$ & $186 \cdot 9$ & $413 \cdot 0$ & $232 \cdot 2$ & 0.007 & $418 \cdot 7$ & $142 \cdot 4$ & $521 \cdot 0$ & $139 \cdot 2$ & $<0.001$ & $802 \cdot 0$ & $410 \cdot 3$ & $1640 \cdot 0$ & $606 \cdot 6$ & $<0.001$ \\
\hline Protein (g) & $3 \cdot 3$ & $1 \cdot 1$ & $5 \cdot 4$ & $2 \cdot 4$ & $<0.001$ & $1 \cdot 5$ & 0.9 & $2 \cdot 0$ & 0.6 & 0.071 & $10 \cdot 1$ & $8 \cdot 3$ & $19 \cdot 8$ & $12 \cdot 2$ & $<0.001$ \\
\hline Carbohydrate (g) & $9 \cdot 9$ & $6 \cdot 9$ & $15 \cdot 0$ & $10 \cdot 4$ & 0.003 & $16 \cdot 1$ & $4 \cdot 5$ & $20 \cdot 3$ & $7 \cdot 6$ & $<0.001$ & $23 \cdot 7$ & $8 \cdot 6$ & $47 \cdot 6$ & $20 \cdot 3$ & $<0.001$ \\
\hline Sugars $(\mathrm{g})$ & $9 \cdot 3^{*}$ & $6 \cdot 7$ & $13 \cdot 7$ & $9 \cdot 5$ & 0.004 & $8 \cdot 5$ & $2 \cdot 3$ & $9 \cdot 9$ & $5 \cdot 0$ & 0.094 & $4 \cdot 6$ & 3.0 & $6 \cdot 8$ & $4 \cdot 8$ & 0.000 \\
\hline Fat (g) & $2 \cdot 0$ & $1 \cdot 4$ & 0.9 & $2 \cdot 1$ & 0.001 & $3 \cdot 0$ & $2 \cdot 5$ & $3 \cdot 2$ & $3 \cdot 4$ & 0.112 & $6 \cdot 8$ & $5 \cdot 1$ & $10 \cdot 1$ & $8 \cdot 2$ & $<0.001$ \\
\hline Saturated fat $(\mathrm{g})$ & $1 \cdot 2^{*}$ & 0.9 & 0.4 & $1 \cdot 5$ & $<0.001$ & $1 \cdot 3$ & 0.9 & $1 \cdot 0$ & $1 \cdot 1$ & $<0.001$ & $2 \cdot 4$ & $3 \cdot 4$ & $4 \cdot 0$ & $3 . \overline{5}$ & 0.094 \\
\hline Fibre $(\mathrm{g})$ & $0 \cdot 1^{*}$ & $0 \cdot 2$ & $0 \cdot 3$ & 0.4 & $<0.001$ & $1 \cdot 0$ & $1 \cdot 6$ & $1 \cdot 3$ & $1 \cdot 0$ & 0.071 & $3 \cdot 5$ & $2 \cdot 8$ & $4 \cdot 8$ & $2 \cdot 6$ & $<0.001$ \\
\hline $\mathrm{Na}(\mathrm{g})$ & $0.04^{*}$ & 0.06 & $0 \cdot 10$ & 0.07 & $<0.001$ & 0.08 & 0.05 & 0.05 & 0.07 & $<0.001$ & 0.21 & 0.20 & $0 \cdot 76$ & 0.32 & $<0.001$ \\
\hline $\mathrm{Ca}(\mathrm{mg})$ & $91 \cdot 0^{*}$ & $87 \cdot 0$ & $231 \cdot 8$ & $59 \cdot 9$ & $<0.001$ & $\mathrm{~N} / \mathrm{A}$ & $\mathrm{N} / \mathrm{A}$ & $N / A$ & N/A & - & $\mathrm{N} / \mathrm{A}$ & $\mathrm{N} / \mathrm{A}$ & $\mathrm{N} / \mathrm{A}$ & $\mathrm{N} / \mathrm{A}$ & - \\
\hline
\end{tabular}

C, children's products; NC, non-children's products; IQR, interquartile range; N/A, product information not available.

Significant difference between nutrients, $P<0 \cdot 01$, by Mann-Whitney test

${ }^{*}$ Full product information was unavailable for one children's yoghurt.

Table 3 Fat and sugars content as a percentage of energy and percentage of fat as saturated for products per 100 g; products from seven major UK supermarkets, November 2010-March 2011

\begin{tabular}{|c|c|c|c|c|c|c|c|c|c|c|c|c|c|c|c|}
\hline & \multicolumn{5}{|c|}{ Yoghurts } & \multicolumn{5}{|c|}{ Cereal bars } & \multicolumn{5}{|c|}{ Ready meals } \\
\hline & \multicolumn{2}{|c|}{$\mathrm{C}(n 60)$} & \multicolumn{2}{|c|}{ NC ( $n$ 87) } & \multirow[b]{2}{*}{$P$ value } & \multicolumn{2}{|c|}{$C(n 43)$} & \multicolumn{2}{|c|}{ NC $(n$ 102) } & \multirow[b]{2}{*}{$P$ value } & \multicolumn{2}{|c|}{$\mathrm{C}(n 71)$} & \multicolumn{2}{|c|}{$\mathrm{NC}(n 73)$} & \multirow[b]{2}{*}{$P$ value } \\
\hline & Mean & SD & Mean & SD & & Mean & SD & Mean & SD & & Mean & SD & Mean & SD & \\
\hline$\%$ of energy from fat & $24 \cdot 8$ & $6 \cdot 1$ & $10 \cdot 5$ & $10 \cdot 0$ & $<0.001$ & $26 \cdot 0$ & $7 \cdot 5$ & $26 \cdot 5$ & $10 \cdot 4$ & 0.763 & $27 \cdot 2$ & $10 \cdot 8$ & $25 \cdot 4$ & $10 \cdot 8$ & 0.329 \\
\hline$\%$ of energy from sugars & $48 \cdot 8$ & $8 \cdot 2$ & $54 \cdot 9$ & $10 \cdot 1$ & $<0.001$ & $35 \cdot 8$ & $11 \cdot 6$ & $32 \cdot 4$ & $8 \cdot 2$ & 0.047 & $10 \cdot 9$ & $6 \cdot 9$ & $8 \cdot 0$ & $5 \cdot 0$ & 0.004 \\
\hline$\%$ of fat as saturated & $62 \cdot 4$ & $9 \cdot 9$ & $64 \cdot 9$ & $23 \cdot 8$ & 0.389 & $46 \cdot 7$ & $22 \cdot 6$ & $33 \cdot 4$ & $16 \cdot 2$ & $<0.001$ & $41 \cdot 3$ & $17 \cdot 5$ & $39 \cdot 4$ & $14 \cdot 3$ & 0.472 \\
\hline
\end{tabular}

C, children's products; NC, non-children's products.

Significant difference between nutrients, $P<0 \cdot 01$, by unpaired $t$-test. 
nutrition labelling, it can guide parents of younger children or develop use in older children ${ }^{(50)}$. Parents need more guidance so they are aware that foods considered 'healthier' options for their children are not always the healthiest product available. For example, a children's cereal bar may have less saturated fat than chocolate confectionery, but it may have more saturated fat than a non-children's cereal bar.

Marketing could be used to promote healthier eating in children, but the results from the present study suggest that this opportunity has not been realised. From age 2-8 years children can identify brands, packaging and characters and thus make their own food selections ${ }^{(4,51,52)}$. However, those under 8 years are unable to differentiate between persuasive marketing and information; children are generally less sceptical and lack critical thinking skills until over 11 years old ${ }^{(13,16,53)}$. Studies have shown children preferred snacks and vegetables when a cartoon character was added, compared with identical products without the character ${ }^{(4,16,54)}$. Robinson et al. found that pre-school children favoured foods in a McDonald's wrapper compared with the same food in an unbranded wrapper; this included milk and carrots as well as burgers and fries ${ }^{(52)}$.

The current study raises ethical issues due to the nutritional quality of children's food products. HFSs foods in childhood have implications for obesity, dental caries, insulin resistance and taste preference later in life ${ }^{(10,15)}$. In the UK, the Department of Health claims to work with food manufacturers to increase signposting on products but there is clearly still work to be done ${ }^{(39,55)}$. The UK Department of Health has recently announced plans for a single system for front-of-pack nutrition labelling using both per serving and per $100 \mathrm{~g}$ to aid consumer understanding ${ }^{(56)}$. A drawback of any labelling scheme is applicability to children's products, but this new approach could be used to start work on reaching guidelines on children's products for both industry and consumers to address energy density and portion size issues.

The products chosen for analysis were those deemed as 'healthier' options and likely to comprise a significant proportion of a child's intake. More food types could be included, for example fruit-based snacks, smoothies, cheese snacks and processed meat products; however these food types often have smaller product ranges. Future work could investigate the knowledge and understanding of parents and carers who buy foods marketed at children and explore the interplay between satisfying children's requests and optimising nutritional intake.

\section{Conclusion}

The present study has shown that there is a tendency for products marketed towards children to be less healthy than those aimed at a broader, non-child, general market.
There are significant differences in nutritional contents between categories, raising the question as to why. Would the ideal situation not be to have similar, healthy products with differences in requirements met by varying portion size and food category rather than brand or industry-determined age bracket? The study findings suggest a need for constructive engagement with the food industry and possibly more comprehensive nutritional guidelines for the regulation of food products aimed at children and subsequent marketing of these.

\section{Acknowledgements}

Sources of funding: This research received no specific grant from any funding agency in the public, commercial or not-for-profit sectors. Conflicts of interest: The authors confirm that they have no conflicts of interest. Ethics: Ethical approval was not required. Authors' contributions: A.L. was responsible for the study design, data acquisition, analysis and writing of the manuscript. K.L.R. was responsible for the study concept and contributed to the design, analysis and writing of the manuscript. C.R. contributed to the study design, analysis and the writing of the manuscript. A.M.M. contributed to the writing of the manuscript.

\section{References}

1. Department of Health (2011) Health Profile of England 2010. London: Department of Health; available at http:// www.ic.nhs.uk/statistics-and-data-collections/health-andlifestyles-related-surveys/health-survey-for-england/healthsurvey-for-england-2010-trend-tables

2. European Union (2010) EU Platform on Diet, Physical Activity and Health. 2010 Annual Report. Basel: European Commission; available at http://ec.europa.eu/health/nutrition_ physical_activity/docs/eu_platform_2010frep_en.pdf

3. Han JC, Lawlor DA \& Kimm SY (2010) Childhood obesity. Lancet 375, 1737-1748.

4. McGinnis JM, Gootman JA \& Kraak VI (2006) Food Marketing to Children and Youth: Threat or Opportunity? Washington, DC: National Academies Press; available at http://books.nap.edu/openbook.php?record_id=11514\& page $=\mathrm{R} 1$

5. National Institute for Health and Clinical Excellence (2006) CG43 Obesity: The Prevention, Identification, Assessment and Management of Overweight and Obese Adults and Children. London: NICE; available at http://www.nice.org. uk/nicemedia/live/11000/38294/38294.pdf

6. World Health Organization (2009) WHO Forum and Technical Meeting on Population-based Prevention Strategies for Childhood Obesity. Geneva: WHO.

7. Bates B, Lennox A \& Swan G (2010) National Diet and Nutrition Survey: Headline Results from Year 1 of the Rolling Programme (2008/2009). London: The Stationery Office; available at http://www.food.gov.uk/multimedia/ pdfs/publication/ndnsreport0809.pdf

8. Department of Health (1991) Dietary Reference Values for Food Energy and Nutrients for the United Kingdom. Norwich: HMSO.

9. Elmadfa I (2009) European Nutrition and Health Report 2009. Basel: European Commission; available at http:// www.univie.ac.at/enhr/downloads/enhrii_book.pdf 
10. World Health Organization (2003) Diet, Nutrition and the Prevention of Chronic Diseases. Report of a Joint WHO/FAO Expert Consultation. WHO Technical Report Series no. 916. Geneva: WHO; available at http://whqlibdoc.who.int/trs/ who_trs_916.pdf

11. Ofcom (2007) Television advertising of food and drink products to children. Final statement. http://stakeholders. ofcom.org.uk/consultations/foodads_new/statement/ (accessed October 2010).

12. World Health Organization (2010) Set of Recommendations on the Marketing of Foods and Non-Alcoholic Beverages to Children. Geneva: WHO; available at http://whqlibdoc. who.int/publications/2010/9789241500210_eng.pdf

13. Hastings G, Stead M, McDermott L et al. (2003) Review of the Research on the Effects of Food Promotion to Children. Glasgow: Centre for Social Marketing; available at http://www.food. gov.uk/multimedia/pdfs/foodpromotiontochildren1

14. Harris JL, Schwartz MB \& Brownell KD (2010) Marketing foods to children and adolescents: licensed characters and other promotions on packaged foods in the supermarket. Public Health Nutr 13, 409-417.

15. Hawkes C (2004) Marketing Food to Children: The Global Regulatory Environment. Geneva: WHO; available at http://whqlibdoc.who.int/publications/2004/9241591579.pdf

16. Roberto CA, Baik J, Harris JL et al. (2010) Influence of licensed characters on children's taste and snack preferences. Pediatrics 126, 88-93.

17. Sixsmith R \& Furnham A (2009) A content analysis of British food advertisements aimed at children and adults. Health Promot Int 25, 24-32.

18. Chapman K, Nicholas P, Banovic D et al. (2006) The extent and nature of food promotion directed to children in Australian supermarkets. Health Promot Int 21, 331-339.

19. Kelly B, Hattersley L, King L et al. (2008) Persuasive food marketing to children: use of cartoons and competitions in Australian commercial television advertisements. Health Promot Int 23, 337-344.

20. Jenkin G, Wilson N \& Hermanson N (2009) Identifying 'unhealthy' food advertising on television: a case study applying the UK Nutrient Profile model. Public Health Nutr 12, 614-623.

21. Lobstein T \& Davies S (2009) Defining and labelling 'healthy' and 'unhealthy' food. Public Health Nutr 12, 331-340.

22. World Health Organization (2008) Second WHO European Action Plan for Food and Nutrition Policy 2007-2012. Copenhagen: WHO Regional Office for Europe; available at http://www.euro.who.int/_data/assets/pdf_file/0017/ 74402/E91153.pdf

23. Elliott C (2008) Assessing 'fun foods': nutritional content and analysis of supermarket foods targeted at children. Obes Rev 9, 368-377.

24. Schwartz MB, Vartanian LR, Wharton CM et al. (2008) Examining the nutritional quality of breakfast cereals marketed to children. J Am Diet Assoc 108, 702-705.

25. Livingstone $S$ (2005) Assessing the research base for the policy debate over the effects of food advertising to children. Int J Advert 24, 273-296.

26. Story M \& French S (2004) Food advertising and marketing directed at children and adolescents in the US. Int J Behav Nutr Phys Act 1, 3.

27. Elliott CD (2010) Sweet and salty: nutritional content and analysis of baby and toddler foods. J Public Health 33, 63-70.

28. Department of Health (2012) National Diet and Nutrition Survey: Headline Results from Years 1, 2 and 3 (combined) of the Rolling Programme 2008/9-2010/11. Tables. London: DH; available at http://transparency.dh.gov.uk/2012/07/ 25/ndns-3-years-report/
29. Mintel (2011) Cereal and snack bars - UK - February 2011. http://academic.mintel.com/display/545264/?highlight=true (accessed October 2012).

30. European Commission (2009) Working Document on the Setting of Nutrient Profiles. Brussels: European Commission; available at http://www.aesan.msc.es/AESAN/docs/ docs/notas_prensa/the_setting_of_nutrient_profile.pdf

31. RTS (2010) Western Europe Ready Meals 2010. Wolverhampton: RTS Resource Limited; available at http:// readymealsinfo.com/readymealsinfo.com/reports/Western EuropeReadyMeals2010.pdf

32. Leyland J (2012) Focus On Infant Care: For baby, only the best will do. The Grocer, 21 January 2012; available at http://www.thegrocer.co.uk/fmcg/healthcare-beauty-andbaby/focus-on-infant-care-for-baby-only-the-best-will-do/ 225369.article

33. Elliott CD \& Conlon MJ (2011) Toddler foods, children's foods: assessing sodium in packaged supermarket foods targeted at children. Public Health Nutr 14, 490-498.

34. Kantar Worldpanel (2011) Kantar Worldpanel UK Grocery Market Share Analysis. http://www.kamcity.com/namnews/ mktshare/2011/kantar-march11.htm (accessed September 2012).

35. Food Standards Agency (1996) Food Labelling Regulations 1996. London: FSA; available at http://www.legislation. gov.uk/uksi/1996/1499/made/data.pdf

36. Food Standards Agency (1999) Guidance on Nutrition Labelling. London: FSA; available at http://www.food. gov.uk/multimedia/pdfs/nutlabel2.pdf

37. Food Standards Agency (1993) Food Portion Size. London: Ministry of Agriculture, Fisheries and Food.

38. Department of Health (2006) Forum Packaging Working Group Meeting 22 March 2006. http://www.dh.gov.uk/prod_ consum_dh/groups/dh_digitalassets/@dh/@en/documents/ digitalasset/dh_4134999.pdf (accessed March 2011).

39. Food and Agriculture Organization of the United Nations (2003) Food Energy - Methods of Analysis and Conversion Factors. Food and Nutrition Paper no. 77. Rome: FAO; available at ftp://ftp.fao.org/docrep/fao/006/y5022e/ y5022e00.pdf

40. Food Standards Agency (2007) Front-of-Pack Traffic Light Signpost Labelling. Technical Guidance. London: FSA; available at http://www.food.gov.uk/multimedia/ pdfs/frontofpackguidance2.pdf

41. Institute of Grocery Distribution (2005) Report of the IGD/ PIC Industry Nutrition Strategy Group Technical Working Group on Guideline Daily Amounts (GDAs). Watford: Institute of Grocery Distribution; available at http://www. igd.com $/$ index.asp? $i d=1 \&$ fid $=5 \& \operatorname{sid}=42 \&$ tid $=62 \&$ folid $=0$ $\&$ cid $=592$

42. Food Standards Agency (2008) Salt. Is Your Food Full of It? London: FSA; available at http://tna.europarchive.org/ 20090810121540/http://salt.gov.uk/index.html

43. Webster JL, Dunford EK \& Neal BC (2010) A systematic survey of the sodium contents of processed foods. $A m \mathrm{~J}$ Clin Nutr 91, 413-420.

44. Robertson A (2001) Social inequalities and the burden of food-related ill-health. Public Health Nutr 4, 1371-1373.

45. Cooper S \& Nelson M (2003) 'Economy' line foods from four supermarkets and brand name equivalents: a comparison of their nutrient content and costs. J Hum Nutr Diet 16, 339-347.

46. Darman N, Caillavet F, Joly C et al. (2009) Low-cost foods: how do they compare with their brand name equivalents? A French study. Public Health Nutr 12, 808-815.

47. Burger KS, Kern M \& Colemam KJ (2007) Characteristics of self-selected portion size in young adults. J Am Diet Assoc 107, 611-618.

48. Fisher JO \& Kral TVE (2008) Super-size me: portion size effects on young children's eating. Physiol Behav 94, 39-47. 
49. Grunert KG, Wills JM \& Fernández-Celemín L (2010) Nutrition knowledge, and use and understanding of nutrition information on food labels among consumers in the UK. Appetite 55, 177-189.

50. Campos S, Doxey J \& Hammond D (2011) Nutrition labels on pre-packaged foods: a systematic review. Public Health Nutr 14, 1496-1506.

51. Kopelman CA, Roberts LM \& Adab P (2007) Advertising of food to children: is brand logo recognition related to their food knowledge, eating behaviours and food preferences? J Public Health 29, 358-367.

52. Robinson TN, Borzekowski DLG, Matheson DM et al. (2007) The effects of fast food branding on young children's taste preferences. Arch Pediatr Adolesc Med 161, 792-797.
53. Jones SC, Mannino N \& Green J (2010) 'Like me, want me, buy me, eat me': relationship-building marketing communications in children's magazines. Public Health Nutr 13, 2111-2118.

54. Gunnarsdottir I \& Thorsdottir I (2010) Should we use popular brands to promote healthy eating among children? Public Health Nutr 13, 2064-2067.

55. Food Standards Agency (2004) Action Plan on Food Promotions and Children's Diets. London: FSA; available at http://www.food.gov.uk/multimedia/pdfs/actionplan_ ria.pdf

56. Department of Health (2012) Single system for nutrition labelling announced. http://www.dh.gov.uk/health/2012/ 10/nutrition-labelling/ (accessed November 2012). 